\title{
Exploring Gender Stereotypes through Managerial Process: Implication for Women Advancement, in Case of WolaitaSodo University
}

\author{
Mulatu Dea, Ayalew Shibeshi \\ Department of Educational Planning and Management, Addis Ababa University, Addis Ababa, Ethiopia \\ Email: mulatudea83@yahoo.com, ayalewshibeshi@yahoo.com
}

Received 5 July 2015; accepted 24 July 2015; published 30 July 2015

Copyright (C) 2015 by authors and OALib.

This work is licensed under the Creative Commons Attribution International License (CC BY). http://creativecommons.org/licenses/by/4.0/

(c) (i) Open Access

\begin{abstract}
Despite the fact that there have been a number of research works on gender issues in Ethiopia, little has been done on exploring gender stereotypes through managerial process in higher echelons of leadership position of public universities and its implication for women advancement. Thus, the main objective of this study is to critically explore gender stereotypes though managerial process at WolaitaSodo University and its implications for women advancement. Since the study carried out at the single university level, purposive, availability and random sampling was instrumental for the purpose of this study. Comparisons were done by running cross tabulation of dependent variables across possible explanatory variables. One way ANOVA was also used to see the variation between and within the groups. To analyze the relationship between a set of predictor variables and dependent variables, correlation was employed. SPSS statistics 20 and STATA 11 software packages were used to undertake the statistical analysis. The result reveals that lion share of academic leadership positions of the university is occupied by masculine and women managers are more characterized by communal, relation oriented and transformational leadership behaviors and that the women themselves are reluctant to assume additional responsibilities of the university academic leadership positions and develop poor self-image. It is recommended that aloofness of rules and regulation application, support and encouragement, motivation and aspiration, lack of sex discrimination in hiring and promoting women should be continuously maintained to advance more women to leadership positions of the university and to attract more female to the positions.
\end{abstract}

\section{Keywords}

Gender, Gender Stereotypes, Stereotypes, Managerial Traits, Advancement, Leadership

Subject Areas: Education, Sociology

How to cite this paper: Dea, M. and Shibeshi, A. (2015) Exploring Gender Stereotypes through Managerial Process: Implication for Women Advancement, in Case of WolaitaSodo University. Open Access Library Journal, 2: e1667.

http://dx.doi.org/10.4236/oalib.1101667 


\section{Introduction}

Gender stereotypes are all-encompassing and have an impact on all aspects of women's and men's behavior. Studies on gender stereotypes provide imminent into pervasive expectations that influence how women perceive or view themselves in situations where leadership is required.

Stereotypes are qualities perceived to be associated with particular groups or categories of people [1] and those qualities include traits, expected behaviors, skills, roles and so on. They are the mental categories we make in order to understand culture and one another [2] and are simply generalizations about groups of people [3]. The process by which perceptions of these qualities influence judgments of individuals is called stereotyping.

According to [4], stereotypes derive from observations of the representation of group members in professional roles, such as the role of a manager. Moreover, research shows that women, who are the minority in a male domain such as management, are indeed likely to experience the greatest prejudice and discrimination [5] [6].

Scholars define gender stereotypes in different perspectives. Accordingly, [7] defines gender stereotypes as: "the structured sets of beliefs about the personal attributes of men and women" or "a set of beliefs about the personal attributes of a group of people” (p. 16). They are categorical beliefs regarding the traits and behavioral characteristics ascribed to individuals based on their gender, serve as expectations about the attributes and behaviors of individual group members [8], and are considered as one of the direct antecedents of discrimination at work [9].

People exhibit gender stereotyping when they assign traits, behaviors, skills and roles to individual men and women based on gender. People tend to stereotype men as agentic or self-assertive and motivated to master and women as communal, or selfless and concerned with others [10]-[12].

As a conclusion to this, one could argue that people use stereotypes to form expectations to other people or cultures and to generalize about these in order to fill gaps in their knowledge about different things.

Despite the fact that there have been a number of research works on gender issues in Ethiopia, little has been done on exploring the relationship between gender stereotypes and managerial process. Thus, the main objectives of this study are to critically explore the gender stereotypes through managerial process and its implication on women advancement at WSU and to forward feasible recommendations to the concerned officials of the university to improve the participation of women managers at different levels of the university positions.

\section{Statement of the Problem}

Although the public's attitudes about the role of women in society are undergoing continuous transformation, women still perceived as being less suited than men for managerial positions are. Therefore, unless the root cause of this problem is addressed, glass ceiling will remain firmly in place, and women's participation in leadership over the next decades will remain low [13].

Also [14] contends that one of the greatest obstacles that face women is the attitude they have of themselves. Historically, the idea that man is the jobholder and the breadwinner and females are the home-caretakers or homemakers has been maintained largely.

"In view of this, mothers have always treated their sons with a greater regard than their daughters and this has caused the female self-image, a sense of inferiority. Largely, women have developed a "mental block" and are afraid to break out of this mindset. To overcome this imbalance, women must become more assertive and it is imperative that they shed this inferiority complex" (p. 13).

According to [13] reports that most women aspiring to senior management positions believe the glass-ceiling to career progression still exists. Moreover, according to the survey of 3000 members of the Institute of Leadership and Management (ILM), it was found that 73\% of female respondents felt that barriers still existed for women seeking senior management and board-level positions in the UK. In contrast, just 38\% of men respondents believed that there is a glass-ceiling.

Most importantly [15] asserts that historically, leadership has carried the notion of masculinity, and the belief that men make better leaders than women is still common today. Although the number of female leaders has increased, they are still named as leader as an afterthought (Para 4). [16] also ascertains that the societal conventions regarding gender and leadership have traditionally excluded women, and that top leadership is viewed as a masculine domain.

[17] reports that in the UK, far more women than men are now training to become doctors, professional academicians, senior managers at different institutions and that women consistently achieve higher financial returns 
than men do, making them more likely to provide sound advice on financial investment.

The article went on to state that the governments should embrace the potential of women because they are not exploited enough, they are the world's most under-utilized resource, and getting more of them into work is part of the solution to many economic woes, including shrinking populations and poverty [17].

Yet, in today's fast-paced world, the need for females to balance between their work and family roles has become a matter of paramount importance. They have to take care of their families, and at the same time be professional and successful in their careers. Especially that in today's extremely competitive business world, women constitute half the workforce and are said to play an extremely important role in the economic growth of their [18] [19].

However, what is most worrying is that women are still not advancing to top board level positions, as they should [20]. In spite of the massive entry of women into the workplace and the increasing numbers of women in mid-level managerial positions, top and middle level positions remain as elusive to women today as they were more than a decade ago.

Furthermore, women still believed to be more emotional (subjective), than their male counterparts who are perceived as being logical (objective). This cultural prejudice minimizes the possible chances of women reaching managerial positions.

[19] states that working in a world is dominated by male decision-makers and their established practices. Women encounter a variety of barriers that impede their progress and advancement to the top of their careers. Placing a glass-ceiling challenge prohibits women from reaching the desired top-level managerial positions and advancement. This glass-ceiling is based on stereotypes, discrimination, and cultural misunderstanding of women's abilities and managerial skills. As a result, very few women are represented at their organization's managerial positions.

In addition to glass ceiling practices, women are also facing lots of other barriers that are eventually leading to fewer women reaching managerial positions. Some of these barriers are: access to training and career paths, the rights to a maternity leave, the right to work part-time, access to child care services, subjection to sexual harassment, discrimination or absence of equal employment opportunity laws [11].

However, Margaret Thatcher is often quoted as saying: "If you want something said, asks a man. "If you want something done, asks a woman" [21]. Prohibiting women from advancing to top managerial positions in organizations can lead to losing a great leadership potential, profitability and organizational effectiveness and efficiency.

It is infer that success today requires organizations to best utilize the talent available to them, irrespective of the gender. Accordingly, to be able to use that talent, barriers to upward mobility for women need to be removed. Such barriers represented in the discrimination against women in the workplace when it comes to promotion, salary, training and advancement opportunity to higher-level managerial positions. In addition, this in turn is causing firms to underutilize a significant part of their work force, resulting in the inefficiency of the organization performance and profitability, economic growth and development as well.

To sum from the above literature perspectives, it is possible to surmise that it is better to empower women to top leadership position in order to use the underutilized potentials and to make the organization more profitable and promoting organizational efficiency and effectiveness. Besides, to maintain the balance of institutional leadership position, women participation in different managerial echelons is paramount importance, in turns, it advances them for assuming more responsibilities and risk taking under the institutional environment. Meanwhile, it can change the perception of society with regard to women to the managerial positions which currently are highly dominated by masculine.

Hence, the current paper sheds light on gender stereotypes through managerial process at WSU managerial positions. Moreover, the paper will suggest practices and applications that university can adopt to remove the barriers that prevent women from advancing to upper positions. Besides, the researcher intends that this research help university managers overcome preconceptions about female managers that may cause the institutions to underutilize a significant part of the work force. To that end, the current research addressed four specific research questions.

1) To what extent do women participate in university managerial positions at WSU as compared to men?

2) To what extent do gender stereotypic (agentic, communal) characteristics attributed to men and women managers at WSU?

3) To what extent do leadership-specific (task-oriented, relationship-oriented, transformational) characteristics attributed to men and women managers at WSU? 
4) What are the major determinants that hinder women's advancement in the academic leadership positions of the university?

\section{Ethical Consideration}

Participants were granted confidentiality and encouraged to develop keen interest to take part in the survey. All respondents remained anonymous. The researcher assured them of the confidentiality of their responses at all times and explained that information and research results would only be disclosed to interested respondents on their request. The researcher acknowledged the responsibilities involved in undertaking the research and affirmed that conclusions would be drawn and recommendations made in accordance with the understanding of the data collected.

\section{Research Design and Methodology}

This section presents the research approach and tools or techniques used in the collection as well as analysis of data for the study. As the literature showed, different methods can be, and have been used to address the various issues involved in research problems, and many areas of research have developed, focusing on various research questions advanced quantitative approach was carried out which capitalizes on the advantages. Exploring gender stereotypes through managerial process at WSU and its implications for women advancement involve quantitative data. It is also argued that the use of advanced quantitative approach reflects an attempt to secure an accurate measurement of the phenomenon in question.

\subsection{Study Setting}

The study conducted within the setting of one of the selected federal public universities, which is WSU. The selection of study site was made in accordance with researcher previous work experience, observation and the number of women who occupy the managerial position at the university.

\subsection{Study Populations}

The populations under this quantitative study were academic leaders, teaching staff, director of the university. These informants selected were based on knowledge and experiences of the university. In addition, the selection of the colleges and departments was based on the number of women involved in managerial positions of the university. Hence, the total number of participants under this study was 80 (Table 1).

A coefficient of internal consistency was calculated by using Cronbach's alpha methodology to check the reliability of the scales. The results for the statements contained in the Gender Stereotypes Assessment Instrument were shown in Table 2.

\subsection{Sampling: Quantitative Study}

Since the study is carried out at the single university level, purposive sampling technique to select sample university, vice academic president, gender office director, colleges/faculties based on researcher previous work experience and observation. Simple random sampling used to select male academic staff participants of the study and availability sampling technique to female participants.

Table 1. Category of participants and research tools used for the study.

\begin{tabular}{cccc}
\hline No & Research instruments & Category of participant & Sample \\
\hline & & Vice president & Male $=1$ \\
& Quantitative instrument-Structured & Deans & 2 Female $\& 2$ male $=4$ \\
questionnaire & Department heads & 4 Female \& 15 male $=19$ \\
& & Director & 1 female \\
& Total & Academic staff & 20 Female \& 35 male $=55$ \\
& & 80 \\
\end{tabular}


Table 2. Coefficients of internal consistency using crombach’s alpha methodology.

\begin{tabular}{cc}
\hline Item Type & Reliability Coefficients \\
\hline Agentic Characteristics & 0.81 \\
Communal Characteristics & 0.84 \\
Task Oriented Behaviors & 0.87 \\
Relation Oriented Behaviors & 0.85 \\
Transformational Leadership Behaviors & 0.93 \\
\hline
\end{tabular}

Thus, proportionate sample respondents for each selected faculty and department in the study sites were selected out of 293 academic staff currently working in the different positions of the university. Hence, the sample size of 80 was determined with $95 \%$ confidence level and 5\% confident limit. All participants were filling out the form with the assistance of researcher who were be responsible for delivering, clarifying and collecting the completed forms. Focal persons from university officials informed by circular letter and through consultative meetings. Their cooperation and facilitation were secure high response rate.

\subsection{Data Analysis}

The quantitative data analysis is predominantly descriptive as its aim is to explore gender stereotypes through managerial process at WSU. The data analysis were follow three phases: Ensuring data integrity by testing whether the response furnished by the participants was applicable. This was involve checking the validity of data to see if there were any inconsistencies across responses in the dataset, to detect erroneous entries introduced in data collection or capturing stages and account for missing responses. Conducting descriptive analysis and it was done by running mean, standard deviation. Conducting comparisons is across and within group through selected statistical tests. This is done by running cross tabulation of dependent variables across possible explanatory variables. One way ANOVA also used to see the variation between and within groups. To analyze the relationship between a set of predictor variables and a dependent variables correlation (Pearson correlations) employed. SPSS statistics 20 and STATA 11 software packages used to undertake the statistical analysis. Tables, graphs, and narrations used to present data.

\section{Presentation and Data Analysis}

This section is devoted to the presentation and data analysis. The first section deals with the characteristics of the respondents in terms of sex, age, educational qualification, academic ranks, current position of the respondents and service years. The second section discusses the main part of the study; the analysis, interpretation of data gathered through questionnaires for diagnosing gender stereotypes, document analysis.

\section{Characteristics of Respondents}

The study targeted on exploring gender stereotypes though managerial process of WolaitaSodo University and its implications for women advancement. Academic staff, middle and top officials were the main sources of information.

Accordingly, 55 (68.7\%) academic staff (20 female and 35 male), 25 (31.25\%) academic leaders (4 female department heads, 15 male department heads, 2 female faculty deans, 2 male faculty deans, 1 female director, 1 academic vice president) total of 80 participants were included in the study. Out of 83 questionnaires distributed to respondents, 80 (96.4\%) were filled out properly and returned on time. Besides, to increase the quality of data, document analysis was made. The basic questions were discussed here under.

\section{Q1. To what extent do women participate in university managerial positions at WSU as compared to men?}

The involvement of women in different echelons of the administrative position in the university is highly vital to encourage other to take their part in the leadership position and meanwhile reduces gender based discrimination which negatively perceived by other groups of people working together for the common shared objectives 
of the university. Though an encouraging involvement of women leaders in academic leadership position exhibited in the university, the research result in the table below reveals that out of 17 sample department only 3 (17.64\%) and out of 8 colleges $2(25 \%)$ and out of 5 directors position only $1(20 \%)$ were occupied by women leaders (Figure 1).

Hence, male counterpart dominated the majority of the academic leadership positions of the university. Besides, even if the president and vice presidents positions assigned by the government body and board of the university in terms of their political commitment, they became reluctant to delegate women for the president, and vice presidents positions of the university. Consequently, all the positions occupied and dominated by the masculine.

Q2. To what extent do gender stereotypic (agentic, communal) characteristics attributed to men and women managers at WSU?

Given the changes in both women's work roles and models of managerial effectiveness, the aim of this research is to assess current perceptions of men, women, and successful managers. Specifically, the purpose of this study is to assess management and gender stereotypes of WolaitaSodo University.

As shown in Table 3, respondents were asked to rate the extent o gender stereotypic (agentic) characteristics attributed to men and women managers in the university. As computed mean value 1.24 (SD = 0.931) for women managers and $2.84(\mathrm{SD}=0.786)$ for men managers were confirmed that men managers are characterized by pursuing one's aims and interests forcefully, sometimes unduly so than women manager (Aggressive). The ANOVA test result $(\mathrm{F}=8.07, \mathrm{P}<0.05)$ showed that there was statistically significant difference in perception among respondents.

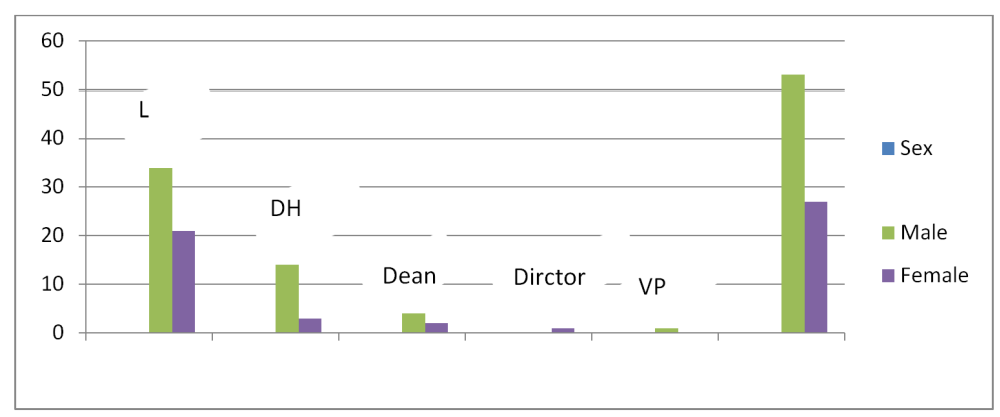

Figure 1. Graphic representation of administrative position of the respondents.

Table 3. Mean ratings and one-way ANOVA results of respondents' responses on agentic characteristics of women and men managers.

\begin{tabular}{|c|c|c|c|c|c|c|c|c|c|c|c|c|}
\hline \multirow{2}{*}{$\begin{array}{c}\text { Agentic } \\
\text { characteristics }\end{array}$} & \multicolumn{6}{|c|}{ Responses on women managers } & \multicolumn{6}{|c|}{ Response on men managers } \\
\hline & M & SD & df & $95 \% \mathrm{CI}$ & $\mathrm{f}$ & $\mathrm{P}>\mathrm{F}$ & Mean & SD & $\mathrm{f}$ & $\mathrm{P}>\mathrm{F}$ & df & $95 \% \mathrm{CI}$ \\
\hline Aggressive & 1.24 & 0.931 & 3 & 1.030 & 1.41 & 0.249 & 2.837 & 0.7866 & 8.07 & 0.000 & 3 & 2.662 \\
\hline Ambitious & 1.96 & 1.163 & 4 & 1.704 & 0.97 & 0.432 & 2.850 & 0.7479 & 1.10 & 0.355 & 3 & 2.683 \\
\hline Analytic & 2.775 & 0.899 & 4 & 2.275 & 0.95 & 0.444 & 2.863 & 0.7753 & 2.00 & 0.123 & 3 & 2.689 \\
\hline Assertive & 2.113 & 0.934 & 4 & 1.906 & 1.11 & 0.362 & 2.837 & 0.6833 & .68 & 0.512 & 2 & 2.685 \\
\hline Dominant & 1.512 & 0.981 & 4 & 1.294 & 0.63 & 0.643 & 2.950 & 0.7274 & .24 & 0.868 & 3 & 2.788 \\
\hline Forceful & 1.563 & 1.077 & 4 & 1.323 & 1.73 & 0.157 & 2.912 & 0.6202 & 2.11 & 0.109 & 3 & 2.774 \\
\hline Self confident & 2.40 & 0.821 & 4 & 2.217 & 1.71 & 0.161 & 2.825 & 0.7252 & 2.37 & 0.103 & 2 & 2.664 \\
\hline
\end{tabular}

Model: a) Partial SS-25.712, DF-27, F-2.03, P > F, 0.0144, R-squared, 0.5185, Adjusted R-squared, 0.2635 (Response on women manager). b) Partial SS-21.001, DF-20, F-2.15, P > F-0.012 R-squared, 0.422, Adjusted R squared, 0.226-(responses on men manager). Source: Mulatu-2014. The Likert Scales are Key: $0=$ Not at all $1=$ Once in a while $2=$ Sometimes $3=$ fairly often $4=$ frequently, if not always. Statistical difference among mean values at $\alpha=0.05$. 
On the same table above, as calculated mean value $1.96(\mathrm{SD}=1.16)$ for women managers and $2.85(\mathrm{SD}=$ 0.749) for men managers were long-established that men managers are showing a strong desire and determination to succeed, or intended to satisfy high aspirations than women managers (Ambitious). The ANOVA test results $(\mathrm{F}=1.10, \mathrm{P}>0.05)$ revealed that there was statistically significant difference in opinion of among the sample respondents.

In other reply, as Yukl (2003) categorized analytic ability as managerial traits exhibited by men managers, it was found out that as calculated mean value $2.77(\mathrm{SD}=0.899)$ for women managers and $2.863(\mathrm{SD}=0.775)$ for men managers confirmed that both managers have the ability to visualize, articulate, and solve both complex and uncomplicated problems and concepts and make decisions that are sensible (analytic ability). The ANOVA test results also reveals that $(\mathrm{F}=2.00, \mathrm{P}<0.05)$ indicated that there was statistically significant difference in the responses of respondents.

In response to the question whether both managers displayed assertiveness or not, as computed mean value $2.11(\mathrm{SD}=0.934)$ for women managers and $2.84(\mathrm{SD}=0.683)$ for men managers established that men managers are having or showing a high confident and forceful personality than women managers. The result of one way ANOVA $(\mathrm{F}=0.68, \mathrm{P}<0.05)$ indicated that there was statistically significant difference in the insight of respondents.

With the same taken, responses obtained from respondents in dominance managerial traits, as calculated mean value $1.51(\mathrm{SD}=0.981)$ for women managers and $2.95(\mathrm{SD}=0.727)$ for men managers confirmed that men managers are more important, powerful, or successful than most or all others or influential as compared to the women managers in the university. The ANOVA test results depicts that $(\mathrm{F}=0.24, \mathrm{P}<0.05)$ there was statistically significant difference in the mean responses of the respondents under the study.

With regard to forcefulness and self-confident managerial traits exhibited by university officials, as computed mean value $1.56(\mathrm{SD}=1.08)$ for women managers and $2.91(\mathrm{SD}=0.620)$ for managers, mean value $2.40(\mathrm{SD}=$ 0.821 ) for women managers respectively confirmed that men managers are highly strong and assertive, vigorous and powerful (forceful) to pursue and achieve organizational objectives than women managers and both managers concerned to trusting in one's abilities, qualities, and judgment (self-confident). The one way ANOVA test results $(\mathrm{F}=2.11, \mathrm{P}<0.05)$ and $(\mathrm{F}=2.3, \mathrm{P}<0.05)$ revealed that, there was statistically significant difference in opinion among respondents.

Table 4 below described about the communal characteristics of both gender in WolaitaSodo University. As portrayed in above table, item 1 , and 2 which is awareness and creativity, as calculated mean values of 2.75 (SD = $0.755)$ and 2.48 (SD = 0.076); $2.66(\mathrm{SD}=0.692)$ and $2.46(\mathrm{SD}=0.081)$ for both women and men managers respectively confirmed that women managers are in a better position to aware of the felling of others and highly characterized by showing an ability to make new things or think of new ideas (creative) than men managers as data showed. The result of one way ANOVA test $(\mathrm{F}=8.4, \mathrm{P}<0.05)$ and $(\mathrm{F}=9.5, \mathrm{P}<0.05)$ indicated that there was statistical significance difference among the mean value of respondents.

Table 4. Mean ratings and one-way ANOVA results of respondents' responses on communal characteristics of women and men manager.

\begin{tabular}{|c|c|c|c|c|c|c|c|c|c|c|c|c|}
\hline \multirow{2}{*}{$\begin{array}{l}\text { Communal } \\
\text { characteristics }\end{array}$} & \multicolumn{6}{|c|}{ Responses on women managers } & \multicolumn{6}{|c|}{ Response on men managers } \\
\hline & Mean & SD & df & $\mathrm{f}$ & $\mathrm{P}>\mathrm{F}$ & $95 \% \mathrm{CI}$ & Mean & SD & df & $\mathrm{f}$ & $\mathrm{P}>\mathrm{F}$ & $95 \% \mathrm{CI}$ \\
\hline Aware & 2.750 & 0.7547 & 3 & 8.4 & 0.000 & 2.582 & 2.487 & 0.0755 & 4 & 3.61 & 0.010 & 2.337 \\
\hline Creative & 2.662 & 0.6925 & 3 & 9.55 & 0.00 & 2.508 & 2.462 & 0.0814 & 3 & 0.430 & 0.730 & 2.300 \\
\hline Helpful & 2.950 & 0.7614 & 3 & 0.80 & 0.498 & 2.781 & 2.162 & 0.0915 & 3 & 0.830 & 0.488 & 1.980 \\
\hline Kind & 3.050 & 0.7614 & 4 & 1.54 & 0.214 & 2.881 & 2.087 & 1.826 & 3 & 0.700 & 0.555 & 2.173 \\
\hline Passive & 2.250 & 0.9612 & 4 & 4.24 & 0.004 & 2.036 & 2.083 & 1.834 & 4 & 2.41 & 0.0593 & 2.166 \\
\hline Submissive & 2.325 & 0.9382 & 4 & 3.46 & 0.013 & 2.116 & 1.987 & 1.827 & 3 & 3.01 & 0.037 & 1.827 \\
\hline Sympathetic & 2.713 & 8143 & 3 & 4.74 & 0.002 & 2.531 & 2.213 & 2.044 & 3 & 1.61 & 0.184 & 2.44 \\
\hline
\end{tabular}

Model: a) Partial. SS-26.74, DF-21, F-4.04, P > F-0.00, R-squared, 0.594, Adjusted R, 0.447 (responses on Women Managers). b) Partial 18.508, DF-20, F-3.12, P > F-0.0004, R squared, 0.514, Adjusted R, squared-0.3497 (on men managers). 
Respondents asked to rate helpfulness and kindness managerial traits. The computed mean values of 2.95 (SD = $0.761)$ and $2.16(\mathrm{SD}=0.091)$; $3.05(\mathrm{SD}=0.761)$ and $2.08(\mathrm{SD}=1.83)$ for women and men managers respectively remarked that women managers are highly concerned about giving or ready to give help to the employee in the institution (helpful), and are of a friendly, generous, or warm-hearted nature, showing sympathy (kind) than men managers as the data depicted. The ANOVA test result $(\mathrm{F}=0.8, \mathrm{P}<0.05)$ and $(\mathrm{F}=1.5, \mathrm{P}<0.05)$ revealed that there was statistically significant difference among the mean values the respondents.

On the other hand, in the same table above the three variables which is passiveness submissiveness, and sympathetic were also rated by the respondents. The results portrays that as calculated mean values $2.25(\mathrm{SD}=0.961)$ and 2.08 (SD = 1.83); $2.32(\mathrm{SD}=0.938)$ and $1.99(\mathrm{SD}=1.82) ; 2.71(\mathrm{SD}=0.814)$ and $2.51(\mathrm{SD}=2.04)$ for women and men managers respectively exhibited women managers are better characterized by accepting or allowing what happens or what others do, without active response or resistance (passive), shying away from saying what you really mean and not seeking to achieve your needs (submissive), and feeling compassion for someone or a situation, or connected by a mutual feeling or passion (sympathetic) than men managers as the evidence revealed. The one way ANOVA test results ( $\mathrm{F}=4.2, \mathrm{P}<0.05),(\mathrm{F}=3.5, \mathrm{P}<0.05),(\mathrm{F}=4.7, \mathrm{P}<0.05)$ confirmed that there was no statistically significance differences among the responses of the respondents respectively.

Q3. To what extent leadership-specific (task-oriented, relationship-oriented, transformational) characteristics attributed to men and women managers differ.

As shown in Table 5, respondents asked to rate their opinion as to the extent of both gender exhibited task oriented behaviors (competent and competitive) or not. The computed mean value of $2.53(\mathrm{SD}=0.711)$ and 2.56 $(\mathrm{SD}=0.708)$; $2.42(\mathrm{SD}=0.759)$ and $2.58(\mathrm{SD}=0.706)$ for women and men respectively. Accordingly, the results reveal that both managers are equally equipped with the necessary ability, knowledge, or skill to do something successfully (competent) and characterized by competition (competitive). The ANOVA test result ( $\mathrm{F}=$ 3.12, $\mathrm{P}<0.05)$ and $(\mathrm{F}=1.92, \mathrm{P}<0.05)$ showed that there was statistically significant difference in perception among respondents.

On the same table, respondent requested to rate other two task oriented behaviors which is decisive and industrious. Accordingly, as calculated mean values of $2.36(\mathrm{SD}=0.831)$ and $2.69(\mathrm{SD}=0.722) ; 2.52(\mathrm{SD}=$ $0.795)$ and $2.53(\mathrm{SD}=0.778)$ for women and men managers respectively. Thus, it is confirmed that men managers are in a better position in showing the ability to make decisions quickly and effectively than women managers. On the other side, both genders are equally diligent and hardworking (industrious). The test results of ANOVA revealed that $(\mathrm{F}=0.79, \mathrm{P}<0.05)$ and $(\mathrm{F}=3.28, \mathrm{P}<0.05)$ indicated that there was statistically significant difference in opinion among the respondents.

In response to the question whether two gender displays other task oriented behaviors like independent and intelligent, it portrays that the calculated mean values of $2.29(\mathrm{SD}=0.679)$ and $2.45(\mathrm{SD}=0.673) ; 2.31(\mathrm{SD}=$ 0.722 ) and $2.46(\mathrm{SD}=0.615)$ for women and men respectively and confirmed that both genders do not subject

Table 5. Mean ratings and one-way ANOVA results of respondents' responses on task oriented behaviors of women and men managers.

\begin{tabular}{|c|c|c|c|c|c|c|c|c|c|c|c|c|}
\hline \multirow{2}{*}{$\begin{array}{l}\text { Task oriented } \\
\text { behaviors }\end{array}$} & \multicolumn{6}{|c|}{ Responses on women managers } & \multicolumn{6}{|c|}{ Response on men managers } \\
\hline & Mean & SD & $\mathrm{df}$ & $\mathrm{f}$ & $\mathrm{P}>\mathrm{F}$ & $95 \%$ CI & Mean & SD & $\mathrm{df}$ & $\mathrm{f}$ & $\mathrm{P}>\mathrm{F}$ & $95 \% \mathrm{CI}$ \\
\hline Competent & 2.538 & 0.711 & 3 & 1.95 & 0.131 & 2.379 & 2.562 & 0.708 & 3 & 3.12 & 0.033 & 2.405 \\
\hline Competitive & 2.413 & 0.759 & 4 & 1.92 & 0.118 & 2.244 & 2.588 & 0.706 & 3 & 1.71 & 0.174 & 2.430 \\
\hline Decisive & 2.362 & 0.831 & 3 & 0.79 & 0.005 & 2.178 & 2.688 & 0.722 & 4 & 1.70 & 0.161 & 2.430 \\
\hline Industrious & 2.525 & 0.795 & 3 & 3.28 & 0.027 & 2.348 & 2.537 & 0.778 & 3 & 3.53 & 0.020 & 2.364 \\
\hline Independent & 2.288 & 0.679 & 3 & 0.74 & 0.535 & 2.136 & 2.450 & 0.673 & 3 & 1.01 & 0.394 & 2.300 \\
\hline Intelligent & 2.313 & 0.722 & 4 & 1.47 & 0.221 & 2.152 & 2.463 & 0.674 & 3 & 0.49 & 0.690 & 2.312 \\
\hline Logical & 2.450 & 0.778 & 3 & 0.56 & 0.643 & 2.277 & 2.463 & 0.615 & 3 & 0.56 & 0.641 & 2.326 \\
\hline
\end{tabular}

Model: a) Partial SS-23.966, DF-20, F-4.44, P > F-0.000, R-squared, 0.6009, Adjusted R-squared, 0.4656. b) Partial SS-25.017, DF-19, F-5.39, P > F-0.000, R-squared, 0.6304, Adjusted R-squared, 0.5133. Source: Mulatu-2014. 
to control by others or not affiliated with a larger controlling unit (independent), and are able to vary its state or action in response to varying situations, varying requirements, and past experience (intelligent). The result of one way ANOVA $(\mathrm{F}=0.74, \mathrm{P}>0.05)$ and $(\mathrm{F}=1.01, \mathrm{P}>0.05) ;(\mathrm{F}=1.47, \mathrm{P}>0.05)$ and $(\mathrm{F}=0.56, \mathrm{P}>0.05)$ for both genders indicated that there was no statistically significant difference in the perception of respondents. The mean difference occurred between the groups by chance.

The respondents also requested to rate the last item of Table 5 job related behavior exhibited by the women and men managers in the university.

Accordingly, the computed mean value of $2.45(\mathrm{SD}=0.778)$ and $2.46(\mathrm{SD}=0.615)$ for women and men managers respectively confirmed that both managers similarly characterized by or capable of clear, sound reasoning (logical) as mean values showed on the table. Additionally, the one way ANOVA test results $(\mathrm{F}=0.56$, $\mathrm{P}>0.05$ ) remarked that there was no statistically significant difference in the mean values of the groups.

Under this section the relation oriented leadership behavioral variables were discussed. In view of that, the first, second and third variables of relation oriented leadership behaviors under Table 6 (compassionate, cooperative, fairness) claimed that the calculated mean values of $3.08(\mathrm{SD}=0.688)$ and $2.213(\mathrm{SD}=0.650)$; 3.15 $(\mathrm{SD}=0.781)$ and $2.28(\mathrm{SD}=0.746) ; 3.21(\mathrm{SD}=0.669)$ and $2.163(\mathrm{SD}=0.787)$ correspondingly, confirmed that women managers are better characterized by having feeling or showing sympathy and concern for others (compassionate), working or acting together willingly for a common purpose or benefit (cooperative), very appropriate to the distribution of goods, benefits, and other outcomes in a society, group, or organization (fair) than men managers as observed from mean values of the groups. The ANOVA test results $(\mathrm{F}=0.73, \mathrm{P}<0.05)$ and $(\mathrm{F}=$ 1.49, $\mathrm{P}<0.05)$; $(\mathrm{F}=0.61, \mathrm{P}<0.05)$ and $(\mathrm{F}=1.89, \mathrm{P}<0.05)$; $(\mathrm{F}=2.4, \mathrm{P}<0.05)$ and $(\mathrm{F}=1.05, \mathrm{P}<0.05)$ depicted that there was statistically significant difference among mean values of the respondents.

As depicted in Table 6 about the other four relations oriented leadership behaviors (good listener, inclusive, intuitive and sociable) were well treated. Consequently, the computed mean value of $3.03(\mathrm{SD}=0.763)$ and 2.22 $(\mathrm{SD}=0.595) ; 2.90(\mathrm{SD}=0.850)$ and $2.25(\mathrm{SD}=689) ; 2.94(\mathrm{SD}=0.735)$ and $2.25(\mathrm{SD}=0.819) ; 3.25(\mathrm{SD}=$ $0.702)$ and $2.25(\mathrm{SD}=0.753)$ for women and men managers respectively claimed that, women managers better characterized by paying full attention not only to what is said but also to the person speaking (good listener), some seemingly irrelevant information, even opposite ideas, opinions or theories become more compatible with each other by analyzing, synthesizing, and modification through women managers (inclusive), using or based on what one feels to be true even without conscious reasoning; instinctive or has the ability to acquire knowledge without inference or the use of reason (intuitive) and finally, women manager are more willing to talk and engage in activities with other people; friendly (sociable) than the men managers as revealed in the mean values

Table 6. Mean ratings and one-way ANOVA results of respondents' responses on relation oriented behaviors of women and men managers.

\begin{tabular}{|c|c|c|c|c|c|c|c|c|c|c|c|c|}
\hline \multirow{2}{*}{$\begin{array}{c}\text { Relation oriented LS } \\
\text { behaviors }\end{array}$} & \multicolumn{6}{|c|}{ Responses on women managers } & \multicolumn{6}{|c|}{ Response on men managers } \\
\hline & Mean & SD & $\mathrm{df}$ & $\mathrm{f}$ & $\mathrm{P}>\mathrm{F}$ & $95 \mathrm{CI}$ & Mean & SD & $\mathrm{df}$ & $\mathrm{f}$ & $\mathrm{P}>\mathrm{F}$ & $95 \mathrm{CI}$ \\
\hline Compassionate & 3.038 & 0.683 & 2 & 0.73 & 0.486 & 2.885 & 2.213 & 0.650 & 3 & 1.49 & 0.228 & 2.068 \\
\hline Cooperative & 3.150 & 0.781 & 4 & 0.61 & 0.656 & 2.976 & 2.275 & 0.746 & 3 & 1.89 & 0.144 & 2.109 \\
\hline Fair & 3.213 & 0.669 & 3 & 20.4 & 0.076 & 3.064 & 2.163 & 0.787 & 4 & 1.05 & 0.391 & 1.987 \\
\hline Good Listener & 3.025 & 0.763 & 3 & 0.36 & 0.779 & 2.855 & 2.225 & 0.595 & 3 & 3.37 & 0.026 & 2.093 \\
\hline Inclusive & 2.90 & 0.850 & 3 & 10.11 & 0.354 & 2.711 & 2.263 & 0.689 & 3 & 1.80 & 0.159 & 2.109 \\
\hline Intuitive & 2.938 & 0.735 & 3 & 0.60 & 0.617 & 2.774 & 2.250 & 0.819 & 3 & .35 & 0.789 & 2.068 \\
\hline Sociable & 3.250 & 0.702 & 3 & 0.60 & 0.617 & 3.094 & 2.250 & 0.753 & 4 & 2.10 & 0.096 & 2.032 \\
\hline Show appreciation & 2.925 & 0.808 & 3 & 2.32 & 0.087 & 2.745 & 2.138 & 0.822 & 4 & .53 & 0.715 & 1.954 \\
\hline Tactful & 3.125 & 0.785 & 3 & 0.45 & 0.721 & 2.950 & 2.175 & 0.897 & 3 & 1.33 & 0.277 & 1.975 \\
\hline Understanding & 3.075 & 0.743 & 3 & 0.14 & 0.932 & 2.909 & 2.400 & 0.739 & 3 & .19 & 0.901 & 2.235 \\
\hline
\end{tabular}

Model: a) Partial SS-22.515, DF-28, F-2.85, P > F-0.0006, R squared, 0.6104, Adjusted R-squared, 0.3965. b) Partial SS-19.744, DF-30, F 2.36, P > F-0.0036, R squared, 0.594, Adjusted R squared, 0.3412. Source Mulatu-2014. 
difference. However, the result of one way ANOVA test $(\mathrm{F}=0.36, \mathrm{p}<0.05)$ and $(\mathrm{F}=3.4, \mathrm{P}<0.05)$; $(\mathrm{F}=1.11$, $\mathrm{P}<0.05)$ and $(\mathrm{F}=1,8, \mathrm{P}<0.05) ;(\mathrm{F}=0.60, \mathrm{P}<0.05)$ and $(\mathrm{F}=0.35, \mathrm{P}<0.05) ;(\mathrm{F}=0.60, \mathrm{P}<0.05)$ and $(\mathrm{F}=2.1$, $\mathrm{P}<0.05$ ) indicated that there was statistical difference among the mean value of respondents.

The three remaining relation oriented leadership behaviors (show appreciation, tactful, understanding) as portrayed on the table above, the calculated mean values of $2.95(\mathrm{SD}=0.808)$ and $2.14(\mathrm{SD}=0.822) ; 3.13(\mathrm{SD}=$ $0.708)$ and $2.18(\mathrm{SD}=0.897) ; 3.08(\mathrm{SD}=743)$ and $2.40(\mathrm{SD}=0.739)$ for women and men managers respectively. The results also confirmed that every employee, every team member makes better sacrifice to be part of the organization under women supervision (show appreciation), highly showing tact or being diplomatic, discreet, considerate sensitive, understanding thoughtful, politic and perceptive (tactful), are sympathetically aware of other people's feelings; tolerant and forgiving or the knowledge and ability to judge a particular situation or subject (understanding) than men managers as observed under mean values of group respondents. One-way ANOVA test results $(\mathrm{F}=2.32, \mathrm{P}<0.05)$ and $(\mathrm{F}=0.53(\mathrm{P}<0.05) ;(\mathrm{F}=0.45, \mathrm{P}<0.05)$ and $(\mathrm{F}=1.33, \mathrm{P}<0.05)$; $(\mathrm{F}=0.14, \mathrm{P}<0.05)$ assured that there was significant statistical difference among the mean value of respondents.

Transformational leaders inspire and motivate followers with optimism and commitment to a compelling vision. They link work goals to worker values, challenge established practices, and attend to the individual growth needs of followers [22] [23].

This section also clearly discussed the transformational leadership behaviors exhibited in the WSU as per the response groups. Accordingly, as calculated mean values of the first three variables (considerate, encouraging and energetic) as concerned, $3.06(\mathrm{SD}=0.752)$ and $2.33(\mathrm{SD}=0.742) ; 2.74(\mathrm{SD}=0.689)$ and $2.49(\mathrm{SD}=0.616)$; $2.64(\mathrm{SD}=0.698)$ and $2.69(\mathrm{SD}=0.733)$ respectively for women and men managers. The results depict that women managers in a better position to showing kindly awareness or regard for another's feelings, circumstances (considerate) always giving hope or promise, giving courage, confidence, or hope to their employees (encouraging). But under the third variable both genders have similar degree of showing or involving great activity or characterized by a high level of energy (energetic) to perform the assigned task in the institution. The results the first two variables also confirmed by one way ANOVA test $(\mathrm{F}=5.5, \mathrm{P}<0.05)$ and $(\mathrm{F}=2.53, \mathrm{P}<$ $0.05) ;(\mathrm{F}=8.5, \mathrm{P}<0.05)$ and $(\mathrm{F}=3.2, \mathrm{P}<0.05)$ indicated that there was statistically significant difference among the mean values of the group responses whereas the third variable $(\mathrm{F}=1.7, \mathrm{P}>0.05)$ and $(\mathrm{F}=1.9, \mathrm{P}<$ 0.05 ) revealed that there was no statistically significant difference among the responses of the groups. The slight standard deviation difference occurred by chance.

The respondents were also requested to rate the other four transformational leadership behaviors like (inspiring, open minded, enthusiastic, optimistic) under Table 7. The calculated mean values of $2.65(\mathrm{SD}=0.817)$

Table 7. Mean ratings and one-way ANOVA results of respondents' responses on transformational leadership behaviors of women and men managers.

\begin{tabular}{|c|c|c|c|c|c|c|c|c|c|c|c|c|}
\hline \multirow{2}{*}{$\begin{array}{l}\text { Transformational } \\
\text { Leadership Behaviors }\end{array}$} & \multicolumn{6}{|c|}{ Responses on Women Managers } & \multicolumn{6}{|c|}{ Response on Men managers } \\
\hline & Mean & SD & df & $\mathrm{F}$ & $\mathrm{P}>\mathrm{F}$ & 95CI. & Mean & SD & $\mathrm{df}$ & $\mathrm{f}$ & $\mathrm{P}>\mathrm{F}$ & $95 \mathrm{CI}$ \\
\hline Considerate & 3.063 & 0.752 & 3 & 5.5 & 0.002 & 2.89 & 2.325 & 0.742 & 4 & 2.53 & 0.05 & 2.16 \\
\hline Encouraging & 2.738 & 0.689 & 3 & 8.49 & 0.0001 & 2.58 & 2.488 & 0.616 & 3 & 3.18 & 0.31 & 2.35 \\
\hline Energetic & 2.638 & 0.698 & 3 & 1.68 & 0.182 & 2.48 & 2.638 & 0.733 & 3 & 1.85 & 0.151 & 2.47 \\
\hline Inspiring & 2.625 & 0.817 & 4 & 4.85 & 0.0021 & 2.44 & 2.538 & 0.716 & 3 & 1.04 & 0.384 & 2.38 \\
\hline Open Minded & 2.638 & 0.716 & 4 & 1.82 & 0.139 & 2.48 & 2.325 & 0.671 & 4 & 1.73 & 0.159 & 2.18 \\
\hline Enthusiastic & 2.800 & 0.818 & 2 & .53 & 0.595 & 2.62 & 2.375 & 0.736 & 3 & 0.61 & 0.612 & 2.24 \\
\hline Optimistic & 2.613 & 0.999 & 4 & 2.00 & 0.108 & 2.39 & 2.388 & 0.684 & 3 & 2.50 & 0.069 & 2.21 \\
\hline Sincere & 3.025 & 0.811 & 3 & 2.01 & 0.124 & 2.85 & 2.263 & 0.838 & 3 & 1.35 & 0.269 & 2.08 \\
\hline Supportive & 3.188 & 0.638 & 2 & .82 & 0.044 & 3.05 & 2.250 & 0.878 & 3 & .25 & 0.862 & 2.06 \\
\hline Trustworthiness & 3.036 & 0.787 & 3 & 2.80 & 0.049 & 2.86 & 2.400 & 722 & 3 & 2.31 & 0.087 & 2.24 \\
\hline
\end{tabular}

Model: a) Partial SS-35.70, DF-28, F-7.24, P > F-0.0000, R squared, 0.7989, Adjusted R-squared, 0.6885. b) Partial SS-29.45, DF-28, F-3.80, P > F-0.0000, R squared, 0.6267, Adjusted R squared, 0.4985. Source: Own-2014. 
and $2.54(\mathrm{SD}=0.716) ; 2.64(\mathrm{SD}=716)$ and $2.34(\mathrm{SD}=0.671) ; 2.8(\mathrm{SD}=0.818)$ and $2.4(\mathrm{SD}=0.736) ; 2.61$ $(\mathrm{SD}=0.999)$ and $2.4(\mathrm{SD}=0.684)$ respectively for women and men managers remarked that both women and men managers similarly trying to fill with a conscious, quickening, \& exalting influence to the employees (inspiring). One way ANOVA test results also $(\mathrm{F}=4.9, \mathrm{P}<0.05)$ and $(\mathrm{F}=1.04, \mathrm{P}>0.05)$ confirmed that there was no statistically significant difference among the mean values of the respondents responses. Whereas the other three remaining variables results confirmed that women managers better characterized by act in the way in which people approach the views and knowledge of others (open mindedness);having or showing intense and eager enjoyment, interest, or approval or being eager, keen, avid, passionate by nature (enthusiastic); and are hopeful and confident about the future or involving about overestimate (optimistic) than men managers as assured from the mean values difference of group responses. One way ANOVA test results $(\mathrm{F}=1.82, \mathrm{P}<0.05)$ and $(\mathrm{F}=1.73, \mathrm{P}<0.05) ;(\mathrm{F}=0.53, \mathrm{P}<0.05)$ and $(\mathrm{F}=0.61, \mathrm{P}<0.05) ;(\mathrm{F}=2, \mathrm{P}<0.05)$ and $(\mathrm{F}=2.5, \mathrm{P}<0.05)$ confirmed that there was statistically significant difference among the mean values of the responses.

The last transformational leadership variables discussed under Table 7 were sincere, supportive and trustworthiness. Accordingly, the results of calculated mean values of the three variables as $3.03(\mathrm{SD}=0.811)$ and 2.26 (SD = 0.838); $3.28(\mathrm{SD}=0.636)$ and $2.25(\mathrm{SD}=0.878)$; $3.05(\mathrm{SD}=0.787)$ and $2.4(\mathrm{SD}=0.722)$ for women and men mangers respectively. The results portrays that women managers are more free from sham or deceit; proceeding from genuine feelings or saying what they genuinely feel or believe; not dishonest or hypocritical (sincere), are in better position to working together with the subordinates to achieve the vision and mission of the organization (supportive) and are highly deserving of trust or confidence, dependable, reliable (trustworthiness) as compared to men managers observed in computed means and standard deviations of group responses.

Table 8 deals about the existence of shared university experiences in the ways how to empower women managers to academic leadership position of the university. As depicted in Table 8, item 1, gender issues expressed through the organization's shared vision, value; women are encouraged to be creative and innovative; women are actively encouraged to operate in a coordinated way; emphasis on teamwork, cooperation among women and men was rated once in a while, sometimes, once a while, sometimes respectively with mean value 1.88 ( $\mathrm{SD}=1.17), 2.24(\mathrm{SD}=1.23), 2.24(\mathrm{SD}=1.2), 2.4(\mathrm{SD}=1.04)$. However, the result of one way ANOVA test $(\mathrm{F}=2.61, \mathrm{p}>0.05),(\mathrm{F}=3.3, \mathrm{P}>0.05),(\mathrm{F}=1.89, \mathrm{P}>0.05),(\mathrm{F}=0.29, \mathrm{P}>0.05)$ respectively indicated that there was no statistical difference among the mean value of respondents.

Thus, the commitment of top officials to find better way of empowering women to academic leadership positions is not satisfactory and ignorant of gender issues to incorporate in shared vision and values, reluctant to team work and encouraging women to be creative and innovative which are essential for organizational success and growth.

In regards to Table 9, the university officials with a computed mean value of 2.12 (SD = 1.24), 2.36 (SD = 1.08), $2.76(\mathrm{SD}=0.779), 2.32(\mathrm{SD}=0.802)$ were rated their responses as once in a while, sometimes, fairly often, and sometimes respectively on four items under structured career orientation. It is infer to that, even if there is clear training and development programs to assist and improve women performance to managerial positions, the university lacks consistent promotion and transfer in changing the status of the both genders to climb the top

Table 8. Mean ratings and one-way ANOVA results of respondents' responses on existence of shared university experiences in terms of gender issues.

\begin{tabular}{|c|c|c|c|c|c|c|}
\hline \multirow{2}{*}{ Existence of shared university experiences in terms of gender issues } & \multicolumn{6}{|c|}{$\begin{array}{l}\text { Officials responses on shared } \\
\text { university experience }\end{array}$} \\
\hline & M & SD & df & $\mathrm{f}$ & $\mathrm{P}>\mathrm{F}$ & $95 \% \mathrm{CI}$ \\
\hline Gender issues expressed through the organization's shared vision, value & 1.88 & 1.17 & 4 & 2.61 & 0.107 & 1.399 \\
\hline Women are encouraged to be creative and innovative & 2.24 & 1.23 & 4 & 3.29 & 0.25 & 1.731 \\
\hline Women are actively encouraged to operate in a coordinated way & 2.24 & 1.2 & 3 & 1.89 & 0.36 & 1.745 \\
\hline $\begin{array}{c}\text { Women and men remain together for long periods to have a tremendous amount of } \\
\text { "shared history" }\end{array}$ & 2.00 & 1.04 & 4 & 1.20 & 0.50 & 1.570 \\
\hline $\begin{array}{c}\text { Employees dependent on the leaders and blindly follow this leader because of the } \\
\text { outcomes }\end{array}$ & 2.32 & .85 & 2 & 0.08 & 0.93 & 1.968 \\
\hline Emphasis on teamwork, cooperation, and among women and men & 2.40 & 1.04 & 1 & 0.29 & 0.65 & 1.970 \\
\hline
\end{tabular}

Model: Partial SS-32.4, DF-22, F-11.78, P > F-0.0811, R squared, 0.9923, Adjusted R squared, 0.9081 (responses from university officials). 
Table 9. Mean ratings and one-way ANOVA results of respondents' responses on structured career orientation within organizational gender issues.

\begin{tabular}{|c|c|c|c|c|c|c|}
\hline \multirow{2}{*}{ Structured career orientation within organizational gender issues } & \multicolumn{6}{|c|}{ Officials responses career orientation with I organizational } \\
\hline & Mean & $\mathrm{SD}$ & df & $\mathrm{F}$ & $\mathrm{P}>\mathrm{F}$ & $95 \% \mathrm{CI}$ \\
\hline $\begin{array}{l}\text { There is consistent promotion and transfers in changing the } \\
\text { status of current job of employees (women and men) equally. }\end{array}$ & 2.12 & 1.236 & 3 & 8.5 & 0.002 & 1.609 \\
\hline $\begin{array}{l}\text { Promotions are decided in order to help the best workers } \\
\text { to reach the highest positions. }\end{array}$ & 2.36 & 1.075 & 3 & 8.5 & 0.002 & 1.916 \\
\hline $\begin{array}{l}\text { There is clear training and development program to assist and } \\
\text { improve women performance for managerial positions. }\end{array}$ & 2.76 & 0.779 & 3 & 0.38 & 0.771 & 2.438 \\
\hline $\begin{array}{c}\text { Women who do their jobs well have good prospects of professional } \\
\text { development and career advancement. }\end{array}$ & 2.32 & 0.802 & 3 & 0.14 & 0.935 & 1.989 \\
\hline
\end{tabular}

Model: Partial SS-32.4, DF-9, F-7.31, P > F-0.0004, R squared, 0.8142, Adjusted R squared, 0.7028 (responses from university officials).

ladder of the academic position.

Even women who do their job well do not have good prospects of professional development and career advancement in the university. One-way ANOVA test results $(\mathrm{F}=8.5, \mathrm{P}<0.05)$ displayed that there was significant statistical difference among the mean value of respondents. For gender empowerment to managerial positions of the university, leadership needs to be ready to accept changes.

Q4. What are the major determinants that hinder women's advancement in the academic leadership positions of the university?

To find out the nature of challenges experienced by women who are associated with university managerial position, the views of both respondents were sought. The respondents response rated the following challenges as "fairly often", family and home responsibilities computed mean value of 3.56 (SD =0.961), lack of support, encouragement, and counseling mean value of $3.34(\mathrm{SD}=1.15)$, reluctances to assume responsibilities 3.28 (SD $=1.02)$, poor self image 3.20 ( $\mathrm{SD}=1.04)$, lacks of personal growth and development \& advancement mean values of $3.08(\mathrm{SD}=1.03)$, sex discrimination in hiring and promoting to managerial positions $2.89(\mathrm{SD}=$ 0.920), lack of aspiration or motivation of women $2.80(\mathrm{SD}=0.918)$ working condition and sex discrimination 2.48 (SD = 1.07), lack of aloofness of rule and regulation application $2.36(\mathrm{SD}=1.34)$ (Table 10$)$.

One way ANOVA test results also ( $\mathrm{F}=0.94, \mathrm{P}<0.05),(\mathrm{F}=4.5, \mathrm{P}<0.05),(\mathrm{F}=3.3, \mathrm{P}<0.05),(\mathrm{F}=4.6, \mathrm{P}<$ 0.05), $(\mathrm{F}=3.89, \mathrm{P}<0.05)$ confirmed that there was statistically significant difference among the mean values of the responses. Thus, the university officials should highly commit to improve the challenges women facing in the university to advance them to the leadership position of the university.

As you can see from Table 11, trust worthiness showed interrelationship with aggressiveness $(\mathrm{r}=-0.31, \mathrm{P}<$ $0.01)$, helpfulness $(\mathrm{r}=0.38, \mathrm{P}<0.01)$, sympathetic $(\mathrm{r}=0.45,=\mathrm{P}<0.01)$, competent $(\mathrm{r}=0.30 \mathrm{P}<0.01)$ and compassionate $(\mathrm{r}=0.37, \mathrm{p}<0.01)$, good listener, $(\mathrm{r}=0.59, \mathrm{p}<0.01)$, sociable $(\mathrm{r}=0.49, \mathrm{P}<0.01)$, considerate ( $\mathrm{r}=0.47, \mathrm{P}<0.01)$, inspiring $(\mathrm{r}=0.53, \mathrm{P}<0.01)$, enthusiastic $(\mathrm{r}=0.41, \mathrm{P}<0.01)$ at significant level. The other transformational behavior such as enthusiastic showed interrelation with helpfulness $(\mathrm{r}=0.33, \mathrm{P}<0.01)$, sympathetic $(\mathrm{r}=0.46, \mathrm{P}<0.01)$, competent $(\mathrm{r}=0.47, \mathrm{P}<0.01)$, independent $(\mathrm{r}=0.33, \mathrm{P}<0.01)$, compassionate $(\mathrm{r}=$ 0.42, $\mathrm{P}<0.01)$, good listener $(\mathrm{r}=0.45, \mathrm{P}<0.01)$, sociable $(\mathrm{r}=0.51, \mathrm{P}<0.01)$, considerate $(\mathrm{r}=0.39, \mathrm{P}<0.01)$, inspiring $(\mathrm{r}=0.34, \mathrm{P}<0.01)$. Inspiring also remarked interrelation with helpfulness, $(\mathrm{r}=0.46, \mathrm{P}<0.01)$, sympathetic $(\mathrm{r}=0.33, \mathrm{P}<0.01)$, competent $(\mathrm{r}=0.31, \mathrm{P}<0.01)$, good listener $(\mathrm{r}=0.45, \mathrm{P}<0.01)$, sociable $(\mathrm{r}=0.34$, $\mathrm{P}<0.01)$, considerate at significant level of $(\mathrm{r}=0.55, \mathrm{P}<0.01)$.

Consideration also revealed the interrelationship with helpfulness $(\mathrm{r}=0.38, \mathrm{P}<0.01)$, sympathetic $(\mathrm{r}=0.48$, $\mathrm{P}<0.01)$, competent $(\mathrm{r}=0.43, \mathrm{P}<0.01)$, compassionate $(\mathrm{r}=0.36, \mathrm{P}<0.01)$, good listener $(\mathrm{r}=0.55, \mathrm{P}<0.01)$, sociable at significant level of $(\mathrm{r}=0.40, \mathrm{P}<0.01)$. Hence, maintaining such factors could be groundwork for women involvement and advancement in the managerial positions of the university meanwhile it reduces the negative stereotypes toward women leadership.

Under relation oriented behaviors sociability correlated with helpfulness $(\mathrm{r}=0.31, \mathrm{P}<0.01)$, sympathetic $(\mathrm{r}=$ 0.37, $\mathrm{P}<0.01)$, competent $(\mathrm{r}=0.54, \mathrm{P}<0.01)$, compassionate $(\mathrm{r}=0.43, \mathrm{P}<0.01)$, good listener at significant level of $(\mathrm{r}=0.41, \mathrm{P}<0.01)$. From the same category good listener depicted the interrelationship with helpfulness $(\mathrm{r}=0.44, \mathrm{P}<0.01)$, sympathetic $(\mathrm{r}=0.5$, $\mathrm{P}<0.01)$, competent $(\mathrm{r}=0.35, \mathrm{P}<0.01)$, compassionate at sig- 
Table 10. Mean ratings and one-way ANOVA results of respondents’ responses on challenges for women advancement to managerial positions.

\begin{tabular}{|c|c|c|c|c|c|c|}
\hline \multirow{2}{*}{ Challenges woman facing in managerial advancement } & \multicolumn{6}{|c|}{ Responses on challenges } \\
\hline & Mean & $\mathrm{SD}$ & df & $\mathrm{F}$ & $\mathrm{P}>\mathrm{F}$ & $95 \% \mathrm{CI}$ \\
\hline Family and home responsibilities & 3.56 & 0.961 & 3 & 0.94 & 0.445 & 2.16 \\
\hline Women reluctances to assume responsibility & 3.28 & 1.02 & 3 & 3.33 & 0.175 & 1.85 \\
\hline Poor self image & 3.20 & 1.04 & 2 & 4.62 & 0.122 & 1.77 \\
\hline Sex discrimination in hiring and promotion & 2.89 & 0.920 & 3 & 2.9 & 0.128 & 1.66 \\
\hline Lack of support, encouragement, and counseling & 3.34 & 1.15 & 3 & 4.51 & 0.124 & 1.57 \\
\hline Lack of aspiration or motivation & 2.80 & 0.918 & 2 & 4.46 & 0.126 & 1.52 \\
\hline Working conditions and sex discrimination & 2.48 & 1.07 & 2 & 2.86 & 0.202 & 2.10 \\
\hline
\end{tabular}

Model: Partial SS-32.4, DF-21.66, F-6.19, P > F-0.079, R squared, 0.977, Adjusted R squared, 0.8195 (responses from university officials). Source: Mulatu-2014.

Table 11. Inter-correlation matrix of selected gender and leadership subscales.

\begin{tabular}{|c|c|c|c|c|c|c|c|c|c|c|c|c|}
\hline & Agentic & \multicolumn{2}{|c|}{ Communal } & \multicolumn{2}{|c|}{ Task Orie. Behavior } & \multicolumn{3}{|c|}{ Relation Orie. Bbehavior } & \multicolumn{4}{|c|}{ Transformational Leadership Behaviors } \\
\hline Items & Aggressive & Helpful S & ympathetic & Competent & Indep. & Compass. & Good L. & Sociable & Considerate & Inspiring & Enthusiastic & Trust Wort. \\
\hline Aggressive & 1 & & & & & & & & & & & \\
\hline \multirow[t]{2}{*}{ Helpful } & -0.1973 & 1 & & & & & & & & & & \\
\hline & 0.0794 & & & & & & & & & & & \\
\hline \multirow[t]{2}{*}{ Sympathetic } & -0.226 & $0.4052^{*}$ & 1 & & & & & & & & & \\
\hline & 0.438 & 0.0002 & & & & & & & & & & \\
\hline \multirow[t]{2}{*}{ Competent } & -0.1954 & 0.1907 & $0.0489^{*}$ & 1 & & & & & & & & \\
\hline & 0.0824 & 0.0902 & 0 & & & & & & & & & \\
\hline \multirow[t]{2}{*}{ Independent } & $-0.2296^{*}$ & & $0.3118^{*}$ & $0.4630^{*}$ & 1 & & & & & & & \\
\hline & 0.0405 & & 0.0049 & 0 & & & & & & & & \\
\hline \multirow[t]{2}{*}{ Compassionate } & $-0.3922^{*}$ & $.3199^{*}$ & $0.4063^{*}$ & $0.2969^{*}$ & & 1 & & & & & & \\
\hline & 0.0003 & 0.0038 & 0.0002 & 0.0075 & & & & & & & & \\
\hline \multirow[t]{2}{*}{ Good Listener } & $-0.2759^{*}$ & $0.4381^{*}$ & $0.5009^{*}$ & $0.3486^{*}$ & $0.2305^{*}$ & $0.4840^{*}$ & 1 & & & & & \\
\hline & 0.0133 & 0 & 0 & 0.0015 & 0.0397 & 0 & & & & & & \\
\hline \multirow[t]{2}{*}{ Sociable } & $-0.1887^{*}$ & $0.3076^{*}$ & $0.3706^{*}$ & $0.5386^{*}$ & 0.1925 & $0.4284^{*}$ & $0.4134^{*}$ & 1 & & & & \\
\hline & 0.0938 & 0.0055 & 0.0007 & 0 & 0.0872 & 0.0001 & 0.0001 & & & & & \\
\hline \multirow[t]{2}{*}{ Considerate } & & $0.3813^{*}$ & $0.4844^{*}$ & $0.4337^{*}$ & & $.3648^{*}$ & $0.5489^{*}$ & $0.4012^{*}$ & 1 & & & \\
\hline & & 0.0005 & 0 & 0.0001 & & 0.0009 & 0 & 0.0002 & & & & \\
\hline \multirow[t]{2}{*}{ Inspiring } & -0.1976 & $0.4578^{*}$ & $0.3305^{*}$ & $0.3079^{*}$ & $0.2425^{*}$ & 0.2069 & $0.5230^{*}$ & $0.3417^{*}$ & $0.5535^{*}$ & 1 & & \\
\hline & 0.079 & 0 & 0.0027 & 0.0055 & 0.0302 & 0.0656 & 0 & 0.0019 & 0 & & & \\
\hline \multirow[t]{2}{*}{ Enthusiastic } & -0.1862 & $.3294^{*}$ & $0.4639^{*}$ & $0.4707^{*}$ & $0.3331^{*}$ & $0.4215^{*}$ & $0.4548^{*}$ & $0.5068^{*}$ & $0.3912^{*}$ & $0.3411^{*}$ & 1 & \\
\hline & 0.0981 & 0.0028 & 0 & 0 & 0.0025 & 0.0001 & 0 & 0 & 0.0003 & 0.002 & & \\
\hline \multirow[t]{2}{*}{$\begin{array}{c}\text { Trust } \\
\text { Worthiness }\end{array}$} & $-0.3061^{*}$ & $0.3836^{*}$ & $0.4518^{*}$ & $0.3032^{*}$ & 0.2166 & $0.3741^{*}$ & $0.5892^{*}$ & $0.4867^{*}$ & $0.4667^{*}$ & $0.5341^{*}$ & $0.4055^{*}$ & 1 \\
\hline & 0.0058 & 0.0004 & 0 & 0.0063 & 0.0536 & 0.0006 & 0 & 0 & 0 & 0 & 0.0002 & \\
\hline
\end{tabular}

Note: $\mathrm{P}<0.05={ }^{*}, \mathrm{P}<0.01={ }^{* *}, \mathrm{P}<0.001={ }^{* * *}$, scale alphas are presented on the diagonal. 
nificant level of $(\mathrm{r}=48, \mathrm{P}<0.01)$. Finally, compassionate from relation oriented behavior associated with aggressiveness $(\mathrm{r}=-0.39, \mathrm{P}<0.01)$, helpfulness $(\mathrm{r}=0.32, \mathrm{P}<0.01)$, sympathetic $(\mathrm{r}=0.41, \mathrm{P}<0.01)$ competent at significant level of $(\mathrm{r}=0.29, \mathrm{P}<0.01)$. Being competent and independent categorized under task oriented behavior. Accordingly, competent correlated with sympathetic at significant level of $(\mathrm{r}=0.05, \mathrm{P}<0.01)$ and being independent portrayed interrelationship with sympathetic $(\mathrm{r}=0.31, \mathrm{P}<0.01)$, and competent at significant level of $(r=0.46, P<0.01)$. Therefore, both women and men managers should commit to maintain such a behavior so as to be positively gender stereotyped by the staff they are leading.

\section{Summary, Conclusions and Recommendation}

This part deals with the summary of the major findings, conclusions and recommendations of the study. The summary part includes brief discussion of the study and summarizes the findings of the study which followed by conclusions. At last, recommendations that are helpful to improve the situation presented.

\subsection{Summary of Findings}

The main objective this study was exploring gender stereotypes and managerial traits at WSU and its implication for women advancement. In order to attain the fundamental objective of the study the procedural steps such as gathering background information from pertinent sources, designing basic questions, developing the instrument of data gathering, choosing methods of identification of respondents and caring out of data analysis were employed.

Within broader objective of the study efforts were made to meet the following specific objectives:

- To assess the level of managerial positions held by both genders at WSU.

- To identify the agentic and communal characteristics exhibited by women and men managers.

- To identify the task and relation oriented and transformational leadership behavior exhibited by women and men managers.

- To explore the major determinants/challenges that hider to bring women to managerial position at WSU?

To this effect, descriptive survey method was employed. A simple random and purposive sampling techniques is used to select 55 academic staff, availability sampling technique to select academic leaders. Therefore, this research consists of 80 respondents.

Relevant data gathered through questionnaire, observation and document analyzed and interpreted using means, percentiles, standard deviation and statistical test such as one way ANOVA and correlation. The STATA and SPSS software version 20 used for analysis. Depending on the result of data presentation and analysis the following major findings were obtained.

\subsection{Demographic Characteristics of Respondents}

Pertaining to respondents' characteristics of the study reveals that, lion share, that is, 35 (43.75) academic staff, 15 (18.75.8\%) department heads, 3 (3.75\%) faculty deans, 1 (1.25\%) of academic vice president respectively were males. Only 4 (5\%) of department heads, 20 (25\%) of academic staff and 2 (2.5\%) of faculty dean and 1 (1.25) director of gender office respondents were females. The data make clear that females' participation in all positions was very insignificant as compared to their male counter parts. In cultural context it reveals that the WSU was experiencing male dominated culture. The larger proportion of respondents, 48 (60\%) of academic staff and academic leaders fall in the age category 26 - 35 years and 36 to 45 respectively. The respondents in academic and academic leaders were matured enough to explain the gender issues of WSU from different perspective.

There was little variation in educational qualification, 44 (55\%) male and 23 (28.75\%) female; 4 (5\%) male academic staff and academic leaders were MA/MSc, and PhD degree holders respectively. This data reveals that the majority of respondents with better qualification to contribute more for the betterment of the university in general and for gender advancement particular.

With regards to academic rank, 42 (52.5\%) male and 24 (30\%) female were lecturer, 8 (10\%) male and 1 (1.25\%) female respondents were assistant professors. There is no associate professor and professor under the sample units of the university.

Though an encouraging involvement of women leaders in academic leadership position exhibited in the uni- 
versity, the research result in the table below reveals that out of 17 sample department only 3 (17.64\%) and out of 8 colleges 2 (25\%) and out of 5 directors position only 1 (20\%) were occupied by women leaders. Hence, male counterpart dominated the majority of the academic leadership positions of the university.

The larger proportion of respondents, in terms of their respective service years they served, more than half of respondents falls down under the category of 2 to 5 which is 44 (65\%) and 6 to 10 which is $23(28.75 \%)$ service years respectively. Hence, the staff was so young to contribute more for the transformation and development of the university in general and the advancement of women to managerial position in particular.

\subsection{Agentic Characteristics}

The result confirmed that, men managers are highly characterized by pursuing one's aims and interests forcefully, sometimes unduly so than women manager (aggressive) and are showing a strong desire and determination to succeed, or intended to satisfy high aspirations than women managers (ambitious).

The computed mean value of 2.77 (SD = 0.899) for women managers and $2.863(\mathrm{SD}=0.775)$ for men managers confirmed that not only men managers but also women managers similarly exhibited the ability to visualize, articulate, and solve both complex and uncomplicated problems and concepts and make decisions that are sensible (analytic ability).

With the mean value of 2.11 (SD = 0.934) for women managers and $2.84(\mathrm{SD}=0.683$ ) for men managers established that men managers are having or showing a high confident and forceful personality than women managers.

As calculated mean value $1.51(\mathrm{SD}=0.981)$ for women managers and $2.95(\mathrm{SD}=0.727)$ for men managers confirmed that men managers are more important, powerful, or successful than most or all others or influential as compared to the women managers in the university (Dominance), $2.91(\mathrm{SD}=0.620)$ for managers, mean value 2.40 ( $\mathrm{SD}=0.821$ ) both managers are in similar position concerned to trusting in one's abilities, qualities, and judgment (self-confident).

\subsection{Communal Characteristics}

As calculated mean values of $2.75(\mathrm{SD}=0.755)$ and $2.48(\mathrm{SD}=0.076) ; 2.66(\mathrm{SD}=0.692)$ and $2.46(\mathrm{SD}=0.081)$ for both women and men managers respectively confirmed that women managers are in a better position to aware of the felling of others and highly characterized by showing an ability to make new things or think of new ideas (creative) than men managers as data showed.

Women managers are highly concerned about giving or ready to give help to the employee in the institution (helpful), and are of a friendly, generous, or warm-hearted nature, showing sympathy (kind) than men managers as the data depicted.

Women managers are better characterized by accepting or allowing what happens or what others do, without active response or resistance (passive), shying away from saying what you really mean and not seeking to achieve your needs (submissive), and feeling compassion for someone or a situation, or connected by a mutual feeling or passion (sympathetic) than men managers as the evidence showed.

\subsection{Task Oriented Behaviors}

As computed mean value $2.53(\mathrm{SD}=0.711)$ and $2.56(\mathrm{SD}=0.708) ; 2.42(\mathrm{SD}=0.759)$ and $2.58(\mathrm{SD}=0.706)$ for women and men respectively reveal that both managers are equally equipped with the necessary ability, knowledge, or skill to do something successfully (competent) and characterized by competition (competitive).

Men managers are in a better position in showing the ability to make decisions quickly and effectively than women managers. On the other side, both genders are equally diligent and hard working (industrious).

As computed mean value of $2.45(\mathrm{SD}=0.778)$ and $2.46(\mathrm{SD}=0.615)$ for women and men managers respectively confirmed that both managers similarly characterized by or capable of clear, sound reasoning (logical) showed on the table. Both genders do not subject to control by others not affiliated with a larger controlling unit (independent), and are able to vary its state or action in response to varying situations, varying requirements, and past experience (intelligent).

\subsection{Relation Oriented Behaviors}

The calculated mean values of $3.08(\mathrm{SD}=0.688)$ and $2.213(\mathrm{SD}=0.650) ; 3.15(\mathrm{SD}=0.781)$ and $2.28(\mathrm{SD}=$ 
0.746); $3.21(\mathrm{SD}=0.669)$ and $2.163(\mathrm{SD}=0.787)$ respectively confirmed that, women managers are better characterized by: Have feeling or showing sympathy and concern for others (compassionate),Working or acting together willingly for a common purpose or benefit (cooperative), Very appropriate to the distribution of goods, benefits, and other outcomes in a society, group, or organization (fair) than men managers as observed from mean values of the groups.

The computed mean value of $3.03(\mathrm{SD}=0.763)$ and $2.22(\mathrm{SD}=0.595) ; 2.90(\mathrm{SD}=0.850)$ and $2.25(\mathrm{SD}=$ 689); $2.94(\mathrm{SD}=0.735)$ and $2.25(\mathrm{SD}=0.819) ; 3.25(\mathrm{SD}=0.702)$ and $2.25(\mathrm{SD}=0.753)$ for women and men managers respectively claimed that, women managers better characterized by: paying full attention not only to what is said but also to the person speaking (good listener), some seemingly irrelevant information, even opposite ideas, opinions or theories become more compatible with each other by analyzing, synthesizing, and modification through women managers (inclusive), using or based on what one feels to be true even without conscious reasoning; instinctive or has the ability to acquire knowledge without inference or the use of reason (intuitive) and finally, women manager are more willing to talk and engage in activities with other people; friendly (sociable) than the men managers as revealed in the mean values difference.

The results also confirmed that, every employee, every team member makes better sacrifice to be part of the organization under women supervision (show appreciation), Highly showing tact or being diplomatic, discreet, considerate sensitive, understanding thoughtful, politic and perceptive (tactful), Are sympathetically aware of other people's feelings; tolerant and forgiving or the knowledge and ability to judge a particular situation or subject (understanding) than men managers as observed under mean values of group respondents.

\subsection{Transformational Leadership Behaviors}

As calculated mean values of the first three variables (considerate, encouraging and energetic) as concerned, $3.06(\mathrm{SD}=0.752)$ and $2.33(\mathrm{SD}=0.742) ; 2.74(\mathrm{SD}=0.689)$ and $2.49(\mathrm{SD}=0.616) ; 2.64(\mathrm{SD}=0.698)$ and 2.69 $(\mathrm{SD}=0.733)$ respectively for women and men managers depicted that, Women managers in a better position to showing kindly awareness or regard for another's feelings, circumstances (considerate) Always giving hope or promise, giving courage, confidence, or hope to their employees (encouraging). But under the third variable both genders have equally share of showing or involving great activity or characterized by a high level of energy (energetic) to perform the assigned task in the institution.

Both women and men managers similarly try to fill with a conscious, quickening, \& exalting influence to the employees (inspiring). Whereas the other three remaining variables results confirmed that women managers better characterized by: Act in the way in which people approach the views and knowledge of others (open mindedness),Having or showing intense and eager enjoyment, interest, or approval or being eager, keen, avid, passionate by nature (enthusiastic) and are hopeful and confident about the future or involving about overestimate (optimistic) than men managers as assured from the mean values difference o group responses.

Furthermore, results portrayed that women managers are: more free from sham or deceit; proceeding from genuine feelings or saying what they genuinely feel or believe; not dishonest or hypocritical (sincere), Are in better position to working together with the subordinates to achieve the vision and mission of the organization (supportive) and are highly deserving of trust or confidence; dependable; reliable (trustworthiness) as compared to men managers observed in computed means and standard deviations of group responses.

\subsection{Existences of Shared Experiences in Terms of Gender Issues}

Leaders were not committed to find better way of advancing women to academic leadership positions, ignorant of gender issues to incorporate in shared vision and values, reluctant to team work, and absence of encouraging women to be creative and innovative which are existed experiences of the university which is highly affect the organizational effectiveness in general and women advancement in particular

\subsection{Structured Career Orientation in Organization}

Even if there is clear training and development programs to assist and improve women performance to managerial positions, the university lacks consistent promotion and transfer in changing the status of the both genders to climb the top ladder of the academic position. Even women who do their job well lack good prospects of professional development and career advancement in the university. 


\subsection{Challenges for Women Advancement to Managerial Positions}

The results showed that respondents rated the following challenges as "fairly often”: Family and home responsibilities computed mean value of 3.56 ( $\mathrm{SD}=0.961)$, lack of support, encouragement, and counseling mean value of $3.34(\mathrm{SD}=1.15)$, reluctances to assume responsibilities $3.28(\mathrm{SD}=1.0,2)$, poor self image $3.20(\mathrm{SD}=1.04)$, lacks of personal growth and development \& advancement mean values of 3.08 (SD = 1.03), sex discrimination in hiring and promoting to managerial positions 2.89 (SD = 0.920), lack of aspiration or motivation of women $2.80(\mathrm{SD}=0.918)$ working condition and sex discrimination $2.48(\mathrm{SD}=1.07)$, lack of aloofness of rule and regulation application $2.36(\mathrm{SD}=1.34)$.

\subsection{Conclusion and Recommendations}

\subsubsection{Conclusions}

The elimination of the negative perceptions and stereotypes about women's leadership styles and abilities that incessantly jeopardizes women's reputation and integrity as professionals [24] would promote women's advancement and empowerment, while simultaneously reducing gender inequity.

Though the presence of government instruments, institutional commitments, policies, programs and strategies can be taken as a turning point for the existing improvements of positive gender stereotypes, this study indicates that there is still a pronounced gender gap in academic leadership positions of the university and women face the most resistance to their leadership and influence in roles that are male-dominated. The data make clear that females' participation in all four positions (department heads, deans, directors and presidential positions) was very insignificant as compared to their male counter parts.

[25] argued agentic characteristics as an attribution of men managers only and typically, women are stereotyped as more communal, this research revealed that women managers also share some of the agentic characteristics exhibited in the university academic leadership positions where as communal characteristics are primarily concerned with the welfare of other people. Thus, the current research depicted that all in all, women managers are in a better position to attributes communal characteristics than men managers.

Task-oriented leadership behaviors emphasize group output; such as establishing objectives and goals, structuring tasks, and evaluating work quality. The result of this research remarked that both women and men managers are similarly displayed the task oriented behaviors. In contrast, relationship-oriented behaviors emphasize supportive personal relationships, a willingness to develop employees and demonstrations of respect and warmth. Based on this perspective, the research results portrayed that, women managers at the university academic leadership position highly attributed to relation oriented characteristics.

Transformational leaders inspire and motivate followers with optimism and commitment to a compelling vision. They link work goals to worker values, challenge established practices, and attend to the individual growth needs of followers. Hence, the results of the current study claimed that women managers also attributed more transformational leadership behaviors.

\subsubsection{The Ways Forwards/Recommendations}

Based on the research findings and conclusions drawn from the study, I recommended the following threads of inquiry for further examination:

- Awareness of higher education's structure and culture is the most important ingredient to leadership success. It is opportune for women to develop the necessary leadership skills and values to acquire and maintain the job they want. Collaboration is foremost in attaining leadership success as it maintains balance and sustainability of one's position.

- Women who are either in leadership positions or aspire to climb the ladder of promotion toward academic leadership positions should not be shy to project feminine traits such as being caring, empathetic, trusting, sharing, and empowering.

- Women who are in the academic leadership positions of the university should attribute agentic, task and relation oriented, transformational leadership behaviors so as to attract more women leaders to the academic positions and maintain balance between male and female managers.

- Regular gender-related awareness creation programs should be given at each the university levels to strengthen the awareness of the subordinates working under university.

- The university top (Boards and Presidents) officials and MoE together should set the concert targets of 
gender proportion that are to be achieved within a certain periods to ensure gender parity in academic leadership positions in all four managerial echelons.

- The university top officials further scale up women's access to wider opportunity in all educational level and programs to advance their competence level for academic leadership positions.

- The women themselves should stop to be reluctant to assume additional responsibility of the university academic leadership positions should avoid poor self-image.

- Aloofness of rules and regulation application, support and encouragement, motivation and aspiration, lack of sex discrimination in hiring and promoting women should continuously maintained to attract more women to leadership positions of the university.

The Ministry of Education and top officials should revisit the policies, programs, strategies used to advance and empower women to decision making and leadership positions in public universities to attract more women to the managerial positions.

\section{References}

[1] Schneider, D.J. (2004) The Psychology of Stereotyping. Guilford Press, New York.

[2] Varner, I. and Beamer, L. (2005) Intercultural Communication in Global Workplace. McGraw-Hill, New York.

[3] Williams, J.E. and Best, D.L. (2005) Measuring Sex Stereotypes: A Thirty-Nation Study. SAGE Publications, Inc., Thousand Oaks.

[4] Eagly, A.H. and Sczesny, S. (2009) Stereotypes about Women, Men, and Leaders: Have Times Changed? In: Barreto, M., Ryan, M.K. and Schmitt, M.T., Eds., The Glass Ceiling in the 21st Century: Understanding Barriers to Gender Equality, American Psychological Association, Washington DC, 21-47. http://dx.doi.org/10.1037/11863-002

[5] King, E.B., Hebl, M.R., George, J.M. and Matusik, S.F. (2010) Understanding Tokenism: Antecedents and Consequences of a Psychological Climate of Gender Inequity. Journal of Management, 36, 482-510. http://dx.doi.org/10.1177/0149206308328508

[6] Voci, A., Hewstone, M., Crisp, R.J. and Rubin, M. (2008) Majority, Minority, and Parity: Effects of Gender and Group Size on Perceived Group Variability. Social Psychology Quarterly, 71, 114-142. http://dx.doi.org/10.1177/019027250807100203

[7] Six, B. and Eckes, T. (1991) A Closer Look at the Complex Structure of Gender Stereotypes. Sex Roles, 24, 57-71. http://dx.doi.org/10.1007/bf00288703

[8] Cleveland, J.N., Stockdale, M. and Murphy, K.R. (2000) Women and Men in Organizations: Sex and Gender Issues at Work. Erlbaum, Mahwah.

[9] Dovidio, J.F. and Hebl, M.R. (2005) Discrimination at the Level of the Individual: Cognitive and Affective Factors. In: Dipboye, R.L. and Colella, A., Eds., Discrimination at Work, Erlbaum, Mahwah, 11-35.

[10] Eagly, A.H. and Steffen, V.J. (1984) Gender Stereotypes Stem from the Distribution of Women and Men into Social Roles. Journal of Personality and Social Psychology, 46, 735-754. http://dx.doi.org/10.1037/0022-3514.46.4.735

[11] Heilman, M.E., Block, C.J. and Martell, R.F. (1995) Sex Stereotypes: Do They Influence Perceptions of Managers? Journal of Social Behavior and Personality, 10, 237-252.

[12] Schein, V.E., Mueller, R. and Jacobsen, C. (1989) The Relationship between Sex Role Stereotypes and Requisite Management Characteristics among College Students. Sex Roles, 20, 103-110. http://dx.doi.org/10.1007/BF00288030

[13] Snowdon, G. (2011) Women Still Face a Glass Ceiling. http://www.guardian.co.uk/society/2011/feb/21/women-glass-ceiling-still-existstop-jobs

[14] Pillay, S. (2005) A Study of the Barriers to Career Progress of Women in an Organization. Master's Dissertation, Nelson Mandela Metropolitan University, Port Elizabeth and George.

[15] Kiamba, J.M. (2008) Women and Leadership Positions: Social and Cultural Barriers to Success. Wagadu: A Journal of Transnational Women's \& Gender Studies, 6.

[16] Gumbi, R.V. (2002) Tracing Differentiation in Gendered Leadership: An Analysis of Differences in Gender Composition in Top Management in Business, Politics and the Civil Service. Gender, Work and Organization, 9, 15-38. http://dx.doi.org/10.1111/1468-0432.00147

[17] Economist. Com (2006) Women in the Workforce. The Importance of Sex: Forget China, India and the Internet: Economic Growth Is Driven by Women. http://www.economist.com/node/6800723

[18] Willemsen, T.M. (2002) Gender Typing of the Successful Manager-A Stereotype Reconsidered. Sex Roles, 46, 385391. http://dx.doi.org/10.1023/A:1020409429645 
[19] Eagly, A.H. (2007) Female Leadership Advantage and Disadvantage: Resolving the Contradictions. Psychology of Women Quarterly, 31, 1-12. http://dx.doi.org/10.1111/j.1471-6402.2007.00326.x

[20] Ryan, M.K. and Haslam, S.A. (2007) The Glass Cliff: Exploring the Dynamics Surrounding the Appointment of Women to Precarious Leadership Positions. Academy of Management Review, 32, 549-572.

http://dx.doi.org/10.5465/AMR.2007.24351856

[21] Sangweni, Y. (2010) Unwritten Rules for Women in the Workplace. http://www.essence.com/2010/02/05/unwritten-rules-for-women-in-theworkplace

[22] Bass, B.M. (1998) Transformational Leadership. Lawrence Erlbaum Assoc, Inc., New York.

[23] Bass, B.M. (1985) Leadership and Performance beyond Expectation. Free Press, New York.

[24] Catalyst (2005) Women “Take Care” Men “Take Charge”: Stereotyping of US Business Leaders Exposed. http://www.catalyst.org/publication

[25] Yukl, G. (2002) Leadership in Organizations. 5. Prentice Hall, Upper Saddle River. 